\title{
Subsidizing Test Prep
}

\author{
by Maxwell Tingle
}

\begin{abstract}
ubsidizing Test Prep is a policy proposal that addresses racial and income disparities in collegegoing and college success. Standardized tests are intended to measure college preparedness but have instead become measures of income, as students who can afford higher-quality test prep tend to receive higher scores. In effect, low-income students have comparatively lower standardized test scores and subsequently face lower rates of college-going and college-success. A national subsidy of standardized test prep will try to: 1) mitigate racial and income disparities in college-going and college success, 2) equalize opportunity for lowincome students in college admissions, and 3) help make standardized tests an indicator of achievement rather than income. I argue that the policy is politically feasible and project that it will cost approximately $\$ 360$ million annually. The subsidy has the potential to be more efficient, in its effect and cost, than similar policies and programs.
\end{abstract}




\section{INTRODUCTION}

Simply put, my policy proposal is to invest in increasing students' scores on college entrance exams by subsidizing the cost of private standardized test preparation (test prep). I suggest that a national subsidy of test prep would benefit low-income students by increasing access to test prep courses outside of the high school curriculum. This paper begins by examining two underlying issues that result in the inequity: 1) the achievement gap and 2) how standardized test scores have become a measure of income rather than achievement. Next, I discuss policies and programs attempting to address these disparities. Then I propose a subsidy of private test prep courses for low-income students. In support, I present economic and policy arguments for the subsidy, analyze its political feasibility, provide a cost breakdown, and consider similar existing programs. Lastly, I consider various challenges of the subsidy.

\section{PROBLEM \#1: THE}

\section{ACHIEVEMENT GAP AND DISPARITIES IN COLLEGE- GOING/COLLEGE SUCCESS}

The achievement gap-or the persistent disparity in educational performance measures observed between groups of students typically defined by socioeconomic status, race/ethnicity, and gender-can be reframed as a problem of unequal learning opportunities. The variances specifically exist between White and Asian American students and their Latino and Black peers. For example, the National Assessment of Educational Progress reports that Black (91\%) and Latino (87\%) students lack proficiency in mathematics at higher rates than their
White (63\%) and Asian American (53\%) counterparts (Flores 2007). Per Wilkins et al. (2006), by 12th grade, Latino and Black students have scores on NAEP's mathematics assessment comparable to 8 th grade White students. These trends of racial disparity are experienced in subjects other than mathematics.

Unequal learning opportunity is also observed in differences in access to qualified teachers, funding per student, and dropout rates. According to Flores (2007), Black, Latino, and low-income students are less likely to have access to experienced and qualified teachers and equitable funding per student. Further, high school dropout rates are higher for Black, Hispanic, and low-income students. The dropout rate is defined as the percentage of 16- to 24-yearolds who are not enrolled in school and do not have high school credentials. In 2009, the rate was 4.8 percent for Blacks and 5.8 percent for Hispanics, while only 2.4 percent for Whites (Chapman et. al. 2011). Low-income students also experienced a 7.4 percent dropout rate compared to 1.4 percent for their peers from high-income families.

Holzer and Neumark (2006) further claim that racial gaps in educational achievement can be attributed to test scores and differing incomes between Black and White families. In fact, Nettles, Millett, and Ready (2003) report that "the average Black student still scores below 75 percent of White students on standardized tests," and go on to assert that low performance on standardized tests also correlates with family income. Thus, when considering standardized tests for college admissions, students from more affluent and educated families are more likely to score higher on standardized tests because they have 
access to higher-quality education and can afford test prep, implying the opposite is true for low-income students. Low-income students do not receive the same level of test prep needed to score well on tests that play a major role in determining higher education admissions and greater social economic mobility later in life.

Disparities experienced by minority students and low-income students are also seen in college enrollment and graduation rates. In terms of college-going and enrollment rates, the United States Department of Education's 2014 data (2015a; Table 302.20) reveals about a ten percent difference between White high school completers and Black and Hispanic high school completers who enrolled in two- and four-year colleges. In 2013, 68.8 percent of White high school completers enrolled in two- and four-year colleges, compared to only 56.7 percent of Black and 59.8 percent Hispanic high school completers. The Department of Education (2015b; Table 302.30) also reports that in 2014, 83.6 percent of recent high-income high school completers were enrolled in two- and four-year colleges, whereas 63.6 percent of middle-income high school completers and 57.8 percent of low-income high school completers were enrolled in two- and four-year colleges. The statistic displays an approximate 26 percent difference between high-income and low-income high school completers who enrolled in two- and four-year colleges. When examining college success and graduation rates, the Department of Education (2015c; Table 326.10) reports that graduation rates for White, Black, and Hispanic first-time, full-time bachelor's degree-seeking students were 43.7 percent, 21.4 percent, and 30.4 percent, respectively, for the cohort that started in 2008 . The statistic reveals about a 22 percent difference in graduation rates between White and Black students, and about a 13 percent difference in graduation rates between White and Hispanic students. The differences in college enrollment and graduation rates exposes the disparities in college-going and college success for lowincome and minority students.

\section{PROBLEM \#2: STANDARDIZED TESTS MEASURE INCOME, NOT ACHIEVEMENT}

Next, I examine how standardized testing has morphed into a measure of income. My proposed reforms, in theory, would reconfigure the tests to measure achievement. The intended purpose of standardized tests is to offer an additional way to measure academic achievement and college preparedness. Yet, how can lowincome students show they are equipped for college if they are not adequately prepared to take standardized tests? Often, low-income students have less access to test prep because they attend lowperforming schools and/or live in lowincome households. In January of 2014, President Obama addressed the problem in a speech to college presidents saying, "We know that when it comes to college advising, and preparing for tests like the ACT and the SAT, lowincome kids are not on a level playing field...We call these standardized tests. They're not standardized. Malia and Sasha, by the time they're in seventh grade at Sidwell School here, are already getting all kinds of advice and this and that and the other. The 
degree of preparation that many of our kids here are getting in advance of actually taking this test tilts the playing field. It's not fair. And it's gotten worse" (Yang 2014).

Nevertheless, colleges look at standardized test scores and GPAs, among other college application materials, to determine an applicant's readiness for college. Though some schools are deciding to not require test scores for admission, commonly referred to as "going test-optional," test scores are still seriously considered by numerous admissions officers.

The fundamental issue is that low-income students, especially lowincome minority students, score lower on standardized tests. Yet, it is a common assumption that test practice and preparation leads to higher scores on standardized tests. The goal of the proposed subsidy is, therefore, to make test prep affordable for low-income students so that they have equal access to private test prep, based on the assumption that when low-income students have access to such resources, they become more likely to score higher on standardized tests and consequently become more competitive college applicants.

The subsidy is proposed for all lowincome students, and not specifically low-income minority students because it is a common misconception that White students use test prep more than minority students. In fact, the opposite is true; "Blacks and Hispanics are more likely than Whites from comparable backgrounds to utilize test preparation" (Alon 2010). Alon's findings underscore that the root of the test score problem is not so much an issue of race, but an issue of income. Buchmann, Condron, and Roscigno's (2010) findings support that income "inequalities in test preparation, particularly costly SAT courses and private tutoring, are notable and have at least moderate consequences for SAT scores and selective college enrollment." Buchmann, Condron, and Roscigno's findings also indicate that students from high-income families can afford more effective test prep services.

\section{EXISTING POLICIES AND PROGRAMS}

Numerous policies and programs have been implemented at both the university and K-12 levels to address issues of the achievement gap, disparities in college-going and college success, and standardized tests' evolution to an income indicator. Numerous studies examine these policies and programs operating across the United States, and the studies present contradicting evidence on the results of these efforts. The lack of consensus on which policies and programs are successful suggests that there is still room for policy and program innovation.

At the state level, "Top x percent" affirmative action policies seek to increase college enrollment of low-income minority students by automatically admitting students who are in the top x percent of their high school class. Texas is one state that has implemented this policy. The University of Texas at Austin, Texas A\&M, and other public universities throughout the state admit students who graduate from Texas high schools in the top ten percent of their class as part of the Texas Ten Percent Plan (Daugherty, Martorell, and McFarlin 2014). Some critics of the "Top x percent" policy argue that it allows for mismatch to occur at more selective 
public colleges, while critics argue that it could do more to increase diversity at public colleges (Daugherty et. al. 2014). The controversy surrounding "Top $\mathrm{x}$ percent" policies suggests opportunity for policy innovation to decrease mismatch programs and increase student diversity. Some universities are also adopting testoptional admissions policies. Test-optional admissions policies attempt to increase enrollment of low-income and minority students by allowing them to apply to college without submitting standardized test scores. The George Washington University, among others, implemented this policy following a growing belief that standardized tests have become more of a measure of student income than academic achievement. Not requiring students to submit standardized test scores as part of their admissions materials is also thought to increase applicant pool size and diversity. Since implementing the policy, The George Washington University (2016), reports that underrepresented minority group enrollment for the freshman class of 2016 increased by 33 percent from the freshman class of 2015 following the introduction of a "test-optional" policy. Although The George Washington University reports an increase in underrepresented minority enrollment, Belasco, Rosinger, and Hearn's (2014) study found that test-optional policies often do more to increase the perceived selectivity of an institution rather than actually increasing enrollment diversity. The debate around test-optional policies brings to light two things. First, it reveals a desire to increase diversity in college admissions on both sides of the argument. Second, the premise of the policy itself suggests inadequacies as to the usefulness of standardized test scores. Hence, there is an opportunity for policies and programs that can help make standardized test scores measures of achievement rather than income.

Several mentoring, counseling, and cohort programs seek to address achievement gap issues and disparities in college-going and college success for K-12 students. Such programs seek to increase the amount of information available about colleges, financial aid, and the application process to low-income students and provide another avenue of support in the form of a mentor. One example of a mentoring/ counseling program is the College Success Foundation in the District of Columbia (2014), which "provide[s] scholarships and mentoring for low-income, high-potential students" in DC public and charter schools. As another example, a cohort program named The Posse Foundation (2014) forms multicultural teams of ten students from the same high school and provides them with mentoring and counseling support, encouraging continuous comradery and support within the groups throughout high school and college. By offering such services, the College Success Foundation, The Posse Foundation, and other programs aim to improve college enrollment, college success, and financial support for low-income and minority students. The proposed test prep subsidy does not create a mentoring or counseling program, but it will afford low-income students an opportunity to receive intensive test prep tutoring, thus providing another connection to someone who can help with the college process.

Finally, there are numerous policies and programs at the K-12 level that confront achievement gap issues and disparities in college-going and college success. One 
$\mathrm{K}-12$ program example is universal pre- $\mathrm{K}$. The District of Columbia introduced its universal pre-K program in 2008, which increased access to early childhood education and improved enrollment rates of Black students (Zhang 2014). Another K-12 program is school vouchers. North Carolina enacted its Opportunity Scholarships program in 2013 to provide vouchers to low-income students to attend private schools to increase access to higher-quality schools. (EdChoice 2017). Several locales have legislation that holds schools accountable for minority test performance. States including, but not limited to, Massachusetts, North Carolina, and Texas passed school accountability laws requiring more transparency in data that tracks the success of students from all backgrounds attending public schools (McKenzie and Kress 2015). Other policies and programs include de-segregation efforts, charter schools, summer school, tutoring programs, training teachers to recognize racial bias, counseling services, and out-of-school support for low-income families. Even with various programs and policies in place, achievement gap issues and disparities in college-going and college success persist. My test prep subsidy falls under K-12 level efforts to improve college preparation and aims to address the same issues in a different way.

\section{POLICY PROPOSAL:}

\section{SUBSIDIZING TEST PREP}

My policy proposal is to invest in increasing low-income students' scores on college entrance exams through a federal test prep subsidy. A federal program would allow students across the country benefit equally from an effort to equalize college admittance opportunities. The policy has the potential to be more efficient, in its effect and cost, than most of the current policies and programs aimed at addressing income and racial disparities in collegegoing and college success.

Recognizing that low-income minorities are more likely to live in highpoverty areas and attend low quality schools with limited resources (Nettles, Millett, and Ready 2003), I propose subsidizing private test prep courses for low-income students. Increasing access to test prep outside of the high school curriculum would benefit low-income students from every racial/ ethnic background whether they go to low-performing or high-performing high schools. The goal is to make private test prep as affordable to low-income students as it is to high-income students, which starts to address the specific problem of income disparities in college-going and college success. Additionally, by design, disparities faced by low-income minority students are also captured in this policy effort.

\section{ARGUMENTS FOR SUBSIDIZING TEST PREP}

Several arguments for subsidizing test prep state that the policy would 1) improve test scores of low-income students and subsequent chances of college admission, 2) make strides in transforming standardized test scores to a measure of achievement instead of income, 3) equalize opportunity rather than result, 4) counteract mismatch problems, and 5) mitigate displacement problems.

\section{Improving Test Scores Increases College- Going}

Test scores play a large role in admissions. Bowen and Bok (1998) recognize that 
grades and standardized test scores are not perfect measures of academic success, but are the measures college admission offices use most often to predict future academic success. Per Vigdor and Clotfelter (2003), retaking standardized tests does in fact lead to increased scores. However, Vigdor and Clotfelter (2003) also found that admissions policies that seek to accept only the highest standardized test scores disadvantage low-income applicants who are less likely to retake standardized tests to get better scores than applicants from high-income families. My subsidy proposal does not cover the cost of retakes, but instead serves as a complement to existing SAT fee waivers for low-income students who seek to retake the standardized test (College Board 2016). Subsidizing test prep presents a solution to equalize access to test prep resources for low-income students. Therefore, instead of facing income-gap barriers, low-income students would be able to theoretically improve their standardized test scores just as much as other students, and higher test scores would subsequently increase their chance of admission.

\section{Test Prep Increases College Success}

I also argue that taking test prep can cause spillover effects that can prepare students for college classes and tests and also equip students to manage test anxiety. Ted Dorsey, the founder of Tutor Ted, argues that test prep tutoring helps students increase subject mastery, develop problem-solving strategies, and build confidence (Quote Ed 2014). Gaining such spillover effects from test prep can make students prepared for future timed tests, critical thinking and problem solving assignments, and learning in general. Additionally, benefits of test prep, including learning testtaking strategies and engaging in review and practice, are both practices used to help reduce test anxiety experienced by students (Frenette 2015). Engaging in test prep, therefore, not only equips students to manage test anxiety for standardized tests, but also exposes them to methods to combat future test anxiety in college.

\section{Measuring Achievement Instead of Income}

In a time where universities recognize that standardized tests have become measures of income rather than achievement, and some, like The George Washington University, have implemented test-optional policies, I propose that subsidizing test prep would be preferable because it could 1) help make standardized tests a measure of academic achievement and 2) provide admissions offices with a standardized way of assessing students. Instead of relying on GPA, which is subjective school to school, standardized test scores could be useful measures of educational attainment and academic performance that colleges could use to compare students across the country who have different educational backgrounds, assuming the subsidy leads to standardized test scores becoming an accurate measure of achievement.

\section{Equalizing Opportunity Versus \\ Equalizing Result}

Instead of equalizing result-as in the case of affirmative action policies-test prep subsidies offer a chance to equalize the opportunity for low-income students to enroll in college, while maintaining similar, if not more, economic benefits as affirmative action. I argue that improving test scores by way of increased access 
to test prep enhances the likelihood of college admissions and thus improves chances of minority student enrollment, classroom diversity, and post-graduation equity effects on both society and the individual. Providing an equal opportunity to demonstrate knowledge, in terms of test scores, also increases the likelihood of low-income student enrollment at all colleges and universities, not just toptiered schools. Equalizing opportunity by way of equalizing access to test prep more naturally increases applicant pool diversity and college class diversity. Further, postsecondary degree attainment for lowincome students leads to more educated human capital in the workforce and higher earning potential for the student. Data from the National Center for Education Statistics (2015) supports that males and females who attain a Bachelor's or Associate's degree experience a respective $\$ 23,965$ or $\$ 8,505$ average increase in annual earnings in comparison to the income of their peers who only complete high school.

\section{Counteracting Mismatch Problems}

I predict that subsidizing test prep will counteract mismatch problems because it levels standardized test performance through the equalization of test prep access. Currently, using standardized tests as a factor in admissions decisions discriminates against students attending low-performing high schools and lowincome students who cannot afford test prep materials. However, if a policy tried to decrease the achievement gap and increase test prep resources for lowincome students, standardized test results might become an indicator of academic ability rather than income level. Once standardized test results become a true measure of academic ability, the question is whether colleges would admit low-income students at the same rate as students from higher income families who score the same on a standardized test.

\section{Mitigating Displacement Problems}

Subsidizing test prep would also mitigate the problem of displacement if it replaces equal result practices such as reserves and quotas. In the absence of reserved seats and special consideration for low-income minority students, low-income minority students could be treated fundamentally equal to White and high-performing high school counterparts because test scores would only reflect ability. Therefore, students could be admitted on the merit of their test scores and be better matched to schools that accept their level of achievement, as indicated more accurately after the test prep subsidy.

\section{CONSIDERING POLITICAL FEASIBILITY}

The test prep subsidy is politically feasible because it is designed to address widely recognized disparities and benefit lowincome students. The subsidy would be more politically feasible than providing a subsidy exclusively to low-income minority students because it is more generally based on income and therefore more available to all races/ethnicities. By basing eligibility for the subsidy on income rather than race, the proposed policy benefits both lowincome White and low-income minority students by providing subsidizing private test prep services.

Further, given the recognized disparities faced by minority and lowincome students described in this paper, 
even though this policy will not exclude White students, it will greatly benefit minority students because they are more likely to attend high-poverty schools and face subsequent financial barriers that prevent their access to test prep (Boschma and Brownstein 2016). Therefore, the subsidy's focus on low-income minority students also increases its political feasibility.

\section{CONSIDERING THE SUBSIDY'S COST}

The total cost of subsidizing private test prep courses for low-income students is $\$ 360$ million ( $\$ 1,000$ course cost multiplied by 360,000 low-income students taking advantage of the subsidy), approximately $\$ 1,000$ per student. To calculate the cost of subsidizing private test prep courses for low-income students, I first establish the cost of an instructor-led course and project the number of low-income students who will use the subsidy. Based on the cost of a Princeton Review instructor-led test prep course, which costs between $\$ 1,000$ to $\$ 1,200$ per student (Buchmann et. al. 2010). I assume a $\$ 1,000$ cost per student for an instructor-led test prep course. ${ }^{1}$ The Bureau of Labor Statistics (2013, Table 201.10) projects that in 2017 , about 3.6 million students will enroll in 11th grade,

$1 \quad$ By using $\$ 1,000$ as my estimate, I am theoretically proposing a subsidy that covers $100 \%$ of the cost of the test prep course. First, the cost of the proposed policy could be reduced if the policy were revised to instead consider the willingness-to-pay for test-prep courses of low-income families and instead only cover the difference between willingness-to-pay and the full amount. Second, I feel more comfortable proposing a baseline policy cost estimate that covers $100 \%$ of the course cost, because the $\$ 1,000$ course is still cheaper than the courses that push upwards of $\$ 4,000-\$ 6,000$. when test prep courses are often taught. The National Center for Education Statistics (2010) estimates that about 20 percent of five- to 17 -year-olds are in families living in poverty. Thus, I classify 720,000 (3.6 million $\times 20$ percent) students as lowincome students. Of that, I assume that only 50 percent $(720,000 \times 50$ percent $=$ $360,000)$ will take advantage of the subsidy.

In 1998, Levin $(1998,389)$ made a conservative estimate of a national voucher program and placed the program's cost at $\$ 73$ billion, which was 25 percent of the national education budget at the time. The proposed test prep subsidy, in comparison to Levin's estimate, is less than one percent of the cost of the voucher program. I also conducted additional research of K-12 program interventions in the Institute for Education Statistics' What Works Clearinghouse (WWC) website and selected programs implemented in grades 9-12. Of those programs, I focused on interventions geared toward college-bound students, not dropout students. Programs including Core-Plus Mathematics (WWC 2010), Cognitive Tutor (2016; Gabriel and Richtel 2011), and Building Decision Skills (2010) offer students curriculum to improve math skills and decision making ability, and they cost $\$ 100$ or less per student per year. The cost of this first group of programs covers course textbook costs. Programs including Talent Search (WWC 2006) and Project Grad (2007) seek to improve student high school graduation and college enrollment rates, and they cost $\$ 376$ and $\$ 550$ per student per year, respectively. The program costs for the second group covers minimal services costs. Programs including The Quantum Opportunity Program (2007) and Job Corps (2008) are intensive job training, 
mentoring, and education support services that cost $\$ 5,000^{2}$ and $\$ 19,500$ per student per year, respectively. The program costs of this third group are much higher than the other two groups because the cost covers intensive assistance.

The annual cost per student of subsidizing test prep falls between the second and third group of programs researched - it is not the most expensive program option, but it is not the cheapest. The subsidy's cost, however, makes sense because the subsidy is paying for intensive instructional time in addition to course materials.

\section{CONSIDERING SIMILAR EXISTING PROGRAMS}

There are similar, existing programsfree online services and small nonprofit programs-increasing test prep access for low-income students. Major standardized test and test prep companies, as well as independent websites and nonprofits, offer free online test prep services. For example, ACT (2015) offers low-income students free access to its ACT Online Prep program in addition to its fee waiver program for low-income students taking the ACT. In 2014, The College Board partnered with Khan Academy to offer individualized online SAT test prep services for free (Yang 2014; Khan Academy 2016). Additionally, there are websites such as INeedAPencil, Number2, Majortests, FreeVocabulary, and SATexamprep that offer limited, but free ACT/SAT prep services (Let's Get

2 The Quantum Opportunity Program costs $\$ 22,000$ to $\$ 28,000$ per enrollee over the five-year duration of the program. To present the cost per student per year, I took the average of $\$ 22,000$ and $\$ 28,000$, which is $\$ 25,000$, and divided it by five years to arrive at an estimated average cost of $\$ 5,000$ per student per year.
Ready 2017). As for nonprofit programs, A Bridge for Kids (2015) is California-based and offers low-income students affiliated with its efforts a six-week (eighteenhour online) ACT or SAT test prep class. However, these free test prep programs are all online and do not include in-person instruction from a test prep instructor.

One example of a program offering free test prep services that include in-person instruction is the Admission Possible program. Admission Possible is a nonprofit in Minneapolis, Minnesota that provides approximately 600 low-income teenagers with a 15-week ACT prep course that, on average, helps increase scores by 15 percent (Winerip 2005). The individualized, inperson assistance received for free by the Admission Possible students would cost roughly $\$ 100$ per hour if the services were provided by a private tutoring company (Winerip 2005). If Admission Possible is incurring the full $\$ 100$ per hour cost of the test prep services, then the program would cost approximately $\$ 1,500$ per student, which is relatively similar to the $\$ 1,000$ cost per student for the test prep subsidy I have proposed.

\section{CHALLENGES WITH THE POLICY PROPOSAL}

\section{Additional research is needed to determine theeconomiceffects of subsidizing test prep.} I have made theoretical claims about the effects of subsidizing test prep but further research would help substantiate these claims. Research needs to be conducted to measure low-income students' preferences for applying to college after receiving test prep. Field studies would also help determine the impact subsidizing test prep has on low-income students' test scores 
and level of college readiness. Further, examining the subsequent effects on low-income students' college enrollment levels after receiving test prep would be beneficial in determining the effectiveness of subsidizing test prep. Additionally, studying the role external motivation and support from parents and/or guardians plays in whether students complete test prep courses and use test prep material would be helpful.

\section{Subsidizing test prep is not a "fix-all."}

I am not arguing that subsidizing test prep alone will level the playing field for lowincome and minority students. I present an argument that subsidizing test prep would help make standardized test scores a measure of academic success rather than income, which could help improve the chances of enrollment for low-income students. However, even if students benefit from subsidized test prep and achieve higher scores, they might not have access to capable counselors who can help them navigate the college admissions process and financial aid opportunities. Therefore, even with higher test scores, limited knowledge may prevent students from wanting to or being able to, attend college. I recognize that subsidizing test prep will not fix all the problems associated with the achievement gap, the income gap, and the enrollment gap. Each inequality is a complex and nuanced issue that has multiple causal factors at play. Therefore, simply increasing test prep would not reduce any of the gaps on its own.

\section{Access to private test prep courses is a challenge for low-income students.}

A student's access to private test prep services also impacts the effectiveness of subsidized test prep. Communities surrounding low-performing schools are arguably lower-income communities and would theoretically have less test prep services available since there is not an existing customer base that could afford the services. So, the test prep subsidy will either incentivize test prep services to locate closer to low-performing school communities, or students will face longer travel time and higher costs to get to test prep facilities. Longer travel time and higher travel costs could impose opportunity costs that deter low-income students from using the test prep subsidy.

\section{Private test prep imposes opportunity costs.}

Subsidizing private test prep requires that students attend instructional sessions outside of their normal high school curriculum. One challenge facing the targeted students is the opportunity cost of the additional time needed to complete test prep courses. Some students may work, have extracurricular activities, or have classwork to do outside of normal high school hours. The student may not find the time spent in private test prep instruction to be worth the foregone wages, extracurricular investment, or homework time. Additional research would be helpful in determining low-income students' preferences and demand for private standardized test prep.

\section{CONCLUSION}

Subsidizing test prep presents an opportunity to shift the focus in admissions decisions from equality of result to equality of opportunity. The policy starts to address the underlying issue of improving lowincome students' college-going and college 
success. Increasing access and affordability of test prep for low-income students strengthens the validity of standardized testing, making it the gauge of student ability it was intended to be rather than a measure of family income that it has become. As other policy options rack up billions in government expenditures, I propose the exploration of an alternative policy option that confronts underlying issues, increases chances for low-income students to get into college, and does so in a more cost-effective manner.

\section{REFERENCES}

A Bridge for Kids. 2015. "A Bridge for Kids Helps Boost Low-Income SAT Scores." August 9. http://abridgeforkids.org/latest-news-and-events/partnership-toprovide-sat-prep-free-to-low-income-students/\#.

ACT. 2015. "ACT to Provide Low-Income Students with Free Access to New Version of ACT Online Prep." December 15. http://www.act.org/content/act/en/ newsroom/act-to-provide-low-income-students-with-free-access-to-new-versi. html.

Alon, Sigal. 2010. "Racial Differences in Test Preparation Strategies." The University of North Carolina Press, Social Forces, 89 (2), December 2010. Accessed January 21, 2016. http://people.socsci.tau.ac.il/mu/salon/files/2011/11/Racial_ differences_SFJ_89_2_Alon-final.pdf.

Belasco, Andrew S., Kelly O. Rosinger, and James C. Hearn. 2014. “The Test-Optional Movement and America's Selective Liberal Arts Colleges: A Boon for Equity or Something Else?" Educational Evaluation and Policy Analysis, XX:1-18. Accessed January 30, 2017. doi:10.3102/0162373714537350.

Boschma, Jani, and Ronald Brownstein. 2016. "The Concentration of Poverty in Ameican Schools." The Atlantic, February 29. Accessed January 21, 2017.http:// www.theatlantic.com/education/archive/2016/02/concentration-povertyamerican-schools/471414/.

Bowen, William G., and Derek Bok. 1998. “The Shape of the River." Princeton University Press, May 1998.

Buchmann, Claudia, Dennis J. Condron, and Vincent J. Roscigno. 2010. "Shadow Education, American Style: Test Preparation, the SAT and College Enrollment" Abstract. Social Forces, 89.

Bureau of Labor Statistics (BLS) 2013. Table 203.10. Enrollment in public elementary and secondary schools by level and grade: selected years, fall 1980 through fall 
2025. U.S. Department of Labor. Retrieved on November 11, 2016 from http:// nces.ed.gov/programs/digest/d15/tables/dt15_203.10.asp.

Chapman, Chris, Jennifer Laird, Nicole Ifill and Angelina KewalRamani. 2011. "Trends in High School Dropout and Completion Rates in the United States: 19722009" Compendium Report. US Department of Education. Washington, DC: National Center for Education Statistics. Accessed October 20, 2016. http:// nces.ed.gov/pubsearch.

College Board. 2016. “SAT Fee Waivers.” Accessed January 17, 2017. https:// collegereadiness.collegeboard.org/sat/register/fees/fee-waivers.

College Success Foundation. 2014. “Our Story.” Accessed January 21, 2017. http://www.dccollegesuccessfoundation.org/our-story.

Daugherty, Lindsay, Paco Martorell, and Issac McFarlin, Jr. 2014. “The Texas Ten Percent Plan's Impact on College Enrollment." Education Next Summer 2014: 63-69. Accessed January 21, 2017. http://educationnext.org/texas-ten-percentplans-impact-college-enrollment/.

EdChoice. 2017. "North Carolina - Opportunity Scholarships.” Accessed February 6, 2017. https://www.edchoice.org/school-choice/programs/north-carolinaopportunity-scholarships/.

Flores, Alfinio. 2007. "Examining Disparities in Mathematics Education: Achievement Gap or Opportunity Gap?" The University of North Carolina Press. Accessed and published October 12, 2013. Originally published in High School Journal 91, no.1: 29-42. http://www.jstor.org/stable/40367921.

Frenette, Liza. 2015. “Test stress and academic anxiety." NYSUT United, March 6, 2015. Accessed January 21, 2016. http://www.nysut.org/news/nysut-united/ issues/2015/march-2015/test-stress-and-academic-anxiety.

Gabriel, Trip and Matt Richtel. 2011. "Inflating the Software Report Card." The New York Times, October 8, 2011. Accessed January 21, 2017. http://www.nytimes. com/2011/10/09/technology/a-classroom-software-boom-but-mixed-resultsdespite-the-hype.html.

The George Washington University. 2016. “The George Washington University's New Test Optional Policy Helped Shape a More Diverse Freshman Class.” November 21, 2016. Accessed January 17, 2017. https://mediarelations.gwu.edu/georgewashington-university $\%$ E2\%80\%99s-new-test-optional-policy-helped-shapemore-diverse-freshman-class. 
Holzer, Harry J., and David Neumark. 2006. "Affirmative Action: What Do We Know?" Journal of Policy Analysis and Management 25, no. 2: 463-490. Accessed January 30, 2017. http://www.npc.umich.edu/publications/working_papers/.

Khan Academy. 2016. "Official SAT Practice. "Accessed January 21, 2017. https://www. khanacademy.org/sat.

Let's Get Ready. 2017. "Other Free and Low Cost SAT and College Prep Services." Accessed January 21, 2017. http://www.letsgetready.org/GetStarted/HighSchool-Students/Resources/1/.

Levin, Henry M. 1998. "Educational Vouchers: Effectiveness, Choice and Costs." Journal Policy Analysis and Management, 17, no. 3: 373-392.

McKenzie, William, and Sandy Kress. 2015. "The Big Idea of School Accountability." George W. Bush Presidential Center, February 2, 2015. Accessed January 21, 2017. http://www.bushcenter.org/essays/bigidea/.

National Center for Education Statistics. 2010. Table A.1.a.-6 Percentage of 5- to 17-year-olds in families living in poverty, by district locale and state: 2010 . Retrieved on November 11, 2016 from http://nces.ed.gov/programs/coe/ current_tables.asp.

. 2015. Table 502.20: Median annual earnings, number, and percentage of fulltime year-round workers 25 years old and over, by highest level of educational attainment and sex: 1990 through 2014. In U.S. Department of Education, National Center for Education Statistics (Ed.), Digest of Education Statistics (2015 ed.). Retrieved November 4, 2016, from https://nces.ed.gov/programs/ digest/d15/tables/dt15_502.20.asp?current=yes.

Nettles, Michael T., Catherine M. Millett, and Douglas D. Ready. 2003. "Attacking the African American-White Achievement Gap on College Admissions Tests." Brookings Papers on Education Policy, 215-238. Accessed January 30, 2017. https://doi.org/10.1353/pep.2003.0015.

Quote Ed. 2014. "More Than a Higher Score." Quote Ed, June 29. Accessed January 17, 2017. http://www.quotedapps.com/tag/sat-prep/.

The Posse Foundation. 2014. "We Develop Tomorrow's Leaders." Accessed January 21, 2017. https://www.possefoundation.org/about-posse.

U.S. Department of Education, National Center for Education Statistics. 2015a.

Table 302.20: Percentage of recent high school completers enrolled in 2- and 
4-year colleges, by race/ethnicity: 1960 through 2014. In U.S. Department of Education, National Center for Education Statistics (Ed.), Digest of Education Statistics (2015 ed.). Retrieved November 20, 2016, from https://nces.ed.gov/ programs/digest/d15/tables/dt15_302.20.asp.

. 2015b. Table 302.30: Percentage of recent high school completers enrolled in 2-year and 4-year colleges, by income level: 1975 through 2014. In U.S. Department of Education, National Center for Education Statistics (Ed.), Digest of Education Statistics (2015 ed.). Retrieved November 20, 2016, from https:// nces.ed.gov/programs/digest/d15/tables/dt15_302.30.asp.

. 2015c. Table 326.10: Graduation rate from first institution attended for firsttime, full-time bachelor's degree-seeking students at 4-year postsecondary institutions, by race/ethnicity, time to completion, sex, control of institution, and acceptance rate: Selected cohort entry years, 1996 through 2008. In U.S. Department of Education, National Center for Education Statistics (Ed.), Digest of Education Statistics (2015 ed.). Retrieved November 20, 2016, from https:// nces.ed.gov/programs/digest/d15/tables/dt15_326.10.asp.

U.S. Department of Labor, Bureau of Labor Statistics. 2013. Table 201.10: Enrollment in public elementary and secondary schools by level and grade: selected years, fall 1980 through fall 2025. Retrieved on November 11, 2016 from http://nces. ed.gov/programs/digest/d15/tables/dt15_203.10.asp.

Vigdor, Jacob L. and Charles T. Clotfelter. 2001. "Retaking the SAT." Terry Sandford Institute of Public Policy-Duke University, July 20.

What Works Clearinghouse. 2006. “Talent Search.” U.S. Department of EducationInstitute of Education Statistics. December 28. Accessed January 21, 2017. https://ies.ed.gov/ncee/wwc/Docs/InterventionReports/WWC_Talent_ Search_122806.pd.

. 2007. “The Quantum Opportunity Program.” U.S. Department of Education: Institute of Education Statistics. July 2. Accessed January 21, 2017. https://ies. ed.gov/ncee/wwc/Docs/InterventionReports/WWC_QOP_070207.pdf.

. 2007. July 30. “Project Grad.” U.S. Department of Education Institute of Education Statistics. July 30. Accessed January 21, 2017.https://ies.ed.gov/ncee/ wwc/Docs/InterventionReports/WWC_Project_GRAD_073007.pdf.

. 2008. "Job Corps." U.S. Department of Education-Institute of Education Statistics. April. Accessed January 21, 2017. https://ies.ed.gov/ncee/wwc/Docs/ InterventionReports/WWC_Jobcorps_040108.pdf. 
2010. "Core-Plus Mathematics." U.S. Department of Education Institute of Education Statistics. September. Accessed January 21, 2017. https://ies.ed.gov/ ncee/wwc/Docs/InterventionReports/wwc_coreplus_092110.pdf.

. 2010. "Building Decision Skills." U.S. Department of Education- Institute of Education Statistics. September 8. Accessed January 21, 2017. https://ies.ed.gov/ ncee/wwc/Docs/InterventionReports/WWC_Building_Decision_090806.pdf.

2016. "Cognitive Tutor." U.S. Department of Education-Institute of Education Statistics. June. January 21, 2017. https://ies.ed.gov/ncee/wwc/Docs/ InterventionReports/wwc_cognitivetutor_062116.pdf

Wilkins, Amy, and Education Trust staff. 2006. "Yes We Can: Telling Truths and Dispelling Myths About Race and Education in America." The Education Trust. September 2006. Accessed November 20, 2006. http://www2.edtrust.org/NR/ rdonlyres/DD58DD 01-23A4-4B89-9FD8C11BB072331E/0/YesWeCan.pdf.

Winerip, Michael. 2005. “Test Prep Help for Students Who Can’t Afford Kaplan.” New York Times, November 16. Accessed January 21, 2017. http://www.nytimes. com/2005/11/16/education/test-prep-help-for-students-who-cant-affordkaplan.html?_r=0.

Yang, Jia L. 2014. “The College Board is giving away test prep for free. Why that won't change much.” The Washington Post, March 5. Accessed January 21, 2017. https://www.washingtonpost.com/news/wonk/wp/2014/03/05/why-givingaway-test-prep-for-free-wont-change-much/?utm_term=.3f4a9802af44.

Zhang, Simone. 2014. "A portrait of universal pre-kindergarten in DC." Urban Institute, May 1. Accessed February 6, 2017. http://www.urban.org/urban-wire/portraituniversal-pre-kindergarten-dc. 
MAXWELL TINGLE is a second year Master of Public Administration candidate at the Trachtenberg School where he is focusing on program evaluation. He graduated from the George Washington School of Business in 2015 with a Bachelor of Business Administration in International Business, and is back at GW serving the university as a Presidential Administrative Fellow. Max currently works for GW's Marketing and Creative Services office as a multimedia coordinator where he manages GW's online customer service efforts and helps develop social media content for GW's main accounts. In his free time, he volunteers to help teach international students every-day English, and he writes/produces electronic pop music.

\section{ACKNOWLEDGEMENTS}

The author thanks faculty reviewer Dr. Dylan Conger, Editor-in-Chief Janette Martinez, Associate Editor Brittany Harris, and the whole Policy Perspectives editorial team for their feedback and patience throughout the review process. The author also expresses his gratitude to Dr. Kathryn Newcomer for encouraging him to take Dr. Joe Cordes' Economics in Policy Analysis class for which he wrote this policy brief. Finally, the author thanks his family and friends for their unending love and support. 